\title{
Can a Knowledge Sanctuary also be an Economic Engine? The Marketization of Higher Education as Institutional Boundary Work
}

\author{
Daniel H. Nickolai, Steve G. Hoffman and Mary Nell Trautner* \\ Department of Sociology, University at Buffalo, SUNY
}

\begin{abstract}
Universities, particularly research-intensive ones, have responded to a variety of external and internal influences by retooling their missions, culture, and organizational structures to generate revenue from market opportunities. This has resulted in the marketization of higher education: organizational practices that blur the boundary between knowledge-driven and profit-driven institutions. This blurring has spurred debates and uncertainties over the scope and boundaries of the 21 st century university. We argue that these debates spring from institutional boundary work at the intersection of the three main missions of the contemporary academy: knowledge production, student learning, and satisfying the social charter. These missions can sometimes create areas of synergy, but also tensions that are particularly acute where market logics and business-oriented practices contradict academic values. Within knowledge production, a key dilemma is the extent to which knowledge advancement should aim for transcendence versus revenue generation. Within student learning, the dilemma involves incommensurability between the ideals of democratic citizenship and demonstrable return on investment. Within the social charter mission, the dilemma is over whether the university can serve the public welfare while also facilitating the growth of local and national economies.
\end{abstract}

In his 2011 State of the Union Address, US President Barack Obama suggested that Americans are facing their "Sputnik moment," that the future of the nation's position in the global economy depends on our investments in higher education. These investments will pay off, he assured, in technical and scientific innovations with market potential. His speech neatly captured the orthodox policy wisdom on the relationship between the economy and higher education.

Recent research on the marketization of higher education does not provide nearly as clear-cut an answer. We argue that scholarly (and lay) debates around the perils and promises of this trend are best understood as institutional boundary work over the proper scope of university activity. Boundary work is evident in the perpetual criticisms levied against the research universities (Barnett 2010). Some argue that the research university's "ivory towers" are overfilled with disconnected intellectual elites (Adams 2004; Klein 2005; see also Lam 2010) while others worry that corporate interests have "McDonaldized" it by milking undergraduates to subsidize publicly financed industry research and development (Bok 1982, 1990; Ritzer 1996). The university is at once too exclusive, and too inclusive of students who are bound to fail (Professor X2011). It is too coldly detached to provide political guidance, yet is also too politicized to fulfill its role as an autonomous space for academic freedom and knowledge production (Bok 1982).

We argue that these debates reflect contradictions among the three missions of the 21st century research-intensive university: knowledge production, student learning, and satisfying 
the social charter. Administrators, policymakers, and faculty, along with critics of higher education and of particular campuses, all engage in boundary work aimed at demarcating the proper scope of university pursuits. These boundaries are drawn differently across particular university and college settings, although they are nearly everywhere in some degree of tension. This article focuses on how these dilemmas become particularly acute when and where research universities adopt market-oriented practices and structures.

Within the knowledge production sphere, the key dilemma is the extent to which the pursuit of knowledge should transcend short-term problem solving or serve as a vehicle for immediate social needs and revenue generation. Within the student-learning sphere, the dilemma involves tensions between the ideals of democratic citizenship and demonstrable returns on investment. Within the social charter sphere, the dilemma is whether the university can adequately serve the public welfare and local communities while prioritizing economic growth and for-profit ventures. In each of these dilemmas, scholars have documented institutional boundary work that seeks to demarcate university, industry, and the public. This boundary work includes the growing number of hybrid strategies that seek to re-combine the goal of creating basic knowledge with profit maximization in knowledge production (Owen-Smith and Powell 2002; Stokes 1997), democratic training and accountability metrics in student learning (Joughin 2010), and the public good with economic gain in the social charter (Powell et al. 1996; Thomas 2000; Walshok 2000).

This review is unavoidably far from exhaustive. We focus on sociological research on the marketization of higher education. It is necessarily limited to the history, practices, and organizational models ascendant in the United States and Europe. The indicators of marketization are less elaborated in Europe than in the United States, due to the smaller size of the private university system and the state-centeredness of many European social institutions, which has generally led to a more gradual move towards marketization (Dolenec 2006; Locke 2010). That said, many European research universities exhibit a more developed growth of accountability measures aimed at monitoring research productivity and other higher education "outcomes" (Shore 2011). There is also evidence that market pressures play a major role within the teaching, research, and financial strategies of universities around the globe (Frank and Gabler 2006; Oxlund 2010; Radder 2010; Subotzky 1999). This article focuses primarily on research-intensive public and private universities due to prevailing emphasis of the existing literature. However, we believe that our argument, that the dilemmas of university change are quintessential boundary work, holds across the diversity of university and college forms. Indeed, the character and organizational structure of particular institutions are fundamentally shaped by how they demarcate these very boundaries, a point to which we return in our conclusion.

We begin with an overview of the origins, growth, and marketization of higher education in the United States and Europe. Next we turn to the internal contradictions that animate each of the three main missions of the 21 st century research university, demonstrating that managing these dilemmas is a contested process of policing the borders. In the conclusion, we suggest avenues for future research.

\section{Expanding boundaries: the growth of higher education in the United States and Europe}

\section{United States}

Even in the early years of the American higher education system there were competing visions of its purpose. For example, The Academy of Pennsylvania, founded by political 
and civic leaders in 1749 (later renamed the University of Pennsylvania), was an early deviation from the ministerial origins of early Western universities. Unlike their "Ivy League" peers, the focus was on civic rather than theological education. Pennsylvania's medical school served as an early model for the growth of professional schools in law, medicine, and business and finance. Professional schools proliferated over the next century. Today professional and vocational schools enjoy the greatest growth of any segment of the university system (Menand 2011) and business degrees have become the most common type of major in the United States (U.S. Department of Education 2010).

The rapid development of scientific modes of inquiry, along with a broad array of standardized and rationalized modes of training in the 18th and 19th centuries (Foucault 1973 [1966], 1975), eventually brought about a new mission to many Western colleges and universities. This involved the production of systematic knowledge that was to proceed unfettered by either aristocratic orthodoxy or the growing demands of commerce and industry (Etzkowitz 1998; Jencks and Riesman 1968). Out of this grew the modern American research-intensive university, subsidized primarily by federal and state government commitments to university research aimed at both basic scientific research and problem-driven projects.

These two core missions, instruction and research, coincided, although not without tension (i.e. research professors with lax institutional pressures to devote effort to student learning). Since WWII, there was a significant push to make higher education universally accessible (Gumport 2007). In 1950, private and public colleges and universities educated slightly more than 1 million students apiece. Today, both have grown, but public universities have grown much larger, with nearly 15 million students compared to private colleges's 6 million students (Menand 2011). This expansion held across institutional types, with community and junior colleges exploding at a rate of one school per week in the 1960s (Mulnix 1990).

Several key factors account for this growth. One was the creation of university-based public relations offices aimed at student outreach, an early form of higher education marketing (Mulnix 1990). This outreach grew, in part, from a concerted (and contentious) effort among some elite private colleges to develop more meritocratic admission policies. The President of Harvard, for example, was instrumental in institutionalizing the Educational Testing Service in the 1940s (Lemann 1999). Although legacy entry is still common, standardized tests forged more objectivist criteria and more meritocratic institutions. Elite schools had to adapt, and entrance to elite private universities has become increasingly selective. Consider acceptance into Harvard: in 1940, Harvard accepted 85 percent of its applicants, in 1970, just 20 percent, and a mere six percent in 2010 (Menand 2011).

Most of the growth in higher education occurred between 1945 and 1975, owing to a demographic bulge in the American population combined with a variety of federal initiatives aimed at increasing college access, such as the G. I. Bill, equal opportunity legal reforms, and landmark legislation that provided federal backing for student loans from banks and private lenders (Cohen and Kisker 2010; Jencks and Riesman 1968; Menand 2010). The Higher Education Amendments of 1972 toughened discrimination law in higher education, increased federal funding levels, enhanced supplemental and basic opportunity grants, and created a system in which 90 percent of federal funds were tied to student awards (Leslie and Johnson 1974, 3). Along with changes at the state level, these policies significantly shifted college funding away from government endowments and toward individual student tuition. 
These shifts in the funding structure of American higher education effectively pushed institutions to take on characteristics of market-driven organizations to ensure a steady stream of new students who now had much more discretion in where they would attend. Many colleges turned to management research for outreach programs and marketing schemes (Mulnix 1990). Organizational cultures at the administrative level embraced competitiveness and sought to maximize rankings to appeal to potential students, alumni, and endowments (Sauder and Espeland 2009). Research universities increasingly turned to technology transfer to generate additional revenue (Slaughter and Rhoades 2004).

Over the last three decades, then, many US research-intensive universities have retooled their social charters to include knowledge capitalization and economic growth (Etzkowitz et al. 2000; Geiger and Sá 2008; Krimsky 2004). Scholars have generally attributed this trend to the continued growth of the student body and a heightened awareness of the revenue potential for research programs modeled on the biotech boom of the 1980s (see esp. Radder 2010). In practice, the formal aspects of knowledge capitalization have involved the licensing, marketing, and selling of academic knowledge, as well as the expansion of administrative structures, on-campus commercial incubators, on-campus spin-off and start-up companies, community outreach programs, and instructional models oriented to maximizing revenue generation, university-industry links, and institutional ranking (Sauder and Espeland 2009).

\section{Europe}

Unlike the US system, which has long involved a complex mixture of private and statebased public institutions that are relatively autonomous from the federal government, higher education in Europe traditionally fell under the central State. From 1947, the welfare state regimes in many Western European countries, including Sweden, Norway, the Netherlands, England, Ireland, France, and Germany, considered higher education a public good and largely prevented privatization (Dolenec 2006). Much of higher education's expansion occurred in waves, beginning with the publication of the Committee on Higher Education's 'Robbins report' in 1963. The committee's published findings on British higher education system became the blueprint for higher education policy in England (Moser 1988). The report called for large-scale expansion, gave advanced technology colleges university status, and increased opportunities for college attendance. The report also demarcated four main purposes for higher education: instruction of skills, promotion of general powers of the mind, the advancement of learning, and the transmission of common culture (Mayhew et al. 2004, 68). Eleven new universities opened and participation rates grew from 5 to 14 percent in the United Kingdom in the 1960s (Mayhew et al. 2004, 66).

Higher education continued to expand across much of Western Europe in the 1980s (Dolenec 2006). In Sweden, Norway, and the Netherlands, this growth was well funded by the state, while in the United Kingdom and Germany, state support for education dropped dramatically. As in the United States, the United Kingdom looked to private sources to partially offset the rising costs. In 1985, universities gained legal rights to intellectual property (Etzkowitz et al. 2000). Universities also attempted to attract more nonEuropean Union students who paid more and redirected 20 percent of the funding grant for teaching to subsidize student fees (Locke 2010). With public funding continuing to drop, upfront tuition was introduced in the United Kingdom in 1998.

Since the 1990s, the trend throughout much of European higher education has been to couple expansion with greater institutional autonomy and private investment. However, 
while the United Kingdom is closing the gap, no country has approached the extent of privatization of the US system. While the UK generates 35 percent of funding for higher education from private sources as of 2006, 91 percent of funding in Germany comes from the state, with public support at 85 percent in France, 80 percent in Italy, and 75 percent in Spain (Agasisti and Catalano 2006). The dual support system for universities in the United Kingdom allocates funding through competitive research grants and relative performance on the Research Assessment Exercise (replaced in 2010 by the Research Excellence Framework) that evaluates the activity of researchers in their respective schools (Shore 2008; Shore and Wright 2000). Sweden and Norway have been reluctant to charge tuition fees and Ireland abolished theirs in 1996, but Germany introduced them in 2005 and France dictates "enrollment fees" that are very similar (Dolenec 2006).

Recent trends have significantly escalated tensions around the institutional boundaries and scope of European universities. Mayhew et al. $(2004,68)$ note that that the United Kingdom's 1997 Dearing Report focuses on transforming universities into economic engines that can better leverage their assets within a knowledge-based economy. More recently, the "Browne Review" of the higher education system proposed to do away with tuition caps. In response, the Parliament responded in December of 2010 by raising the tuition cap to $£ 9,000$ per year. Several student and higher education advocates, along with all of the Liberal Democrat members of Parliament, protested this policy as a significant shift of the social charter toward a more market-based model. In addition, the "Lisbon Strategy" of 2000 and the more recent Europe 2020 plan treat higher education and knowledge capitalization as keys to the economic health of the European Union.

While scholars generally agree that Europe is slowly moving towards a more privatized system, the government's continued regulation of course offerings, admissions, and funding in countries like France, Italy, Spain, and Germany coupled with continued financial strain make it unlikely that Europe will replicate the United States in either access or degree of institutional autonomy (Agasisti and Catalano 2006; Etzkowitz et al. 2000; Locke 2010). Instead, European scholars have tended to emphasize an "audit culture" in higher education (Shore 2008), representing a profound shift away from non-profit university governance to for-profit corporate management (Wright and Rabo 2010). Within this audit culture, standardized "accountability" metrics are used to demonstrate organizational processes and outcomes, compare the quality of institutions (Sauder and Espeland 2009), and make consequential decisions.

\section{Policing boundaries: managing the contradictions of university change}

As the research university enters the 21st century, the longstanding missions of teaching, research, and a social charter have been challenged by calls for alternative revenue schemes and increased knowledge capitalization. This raises a very basic question: What is the purpose of higher education? Menand (2011) simplifies the array of answers to this question into three overarching theories. In the first, the purpose of higher education is to conduct a meritocratic sorting of human intelligence over a sustained course of evaluations. A second theory argues that higher education should prepare young adults for pluralist democracy. The third theory suggests that higher education is where people learn specialized knowledge required of advanced economies. Each of these theories draws different boundaries around the core and peripheral activities of universities as well as their proper relationship with the local, state, and national economies and the public good. 
Menand points out that a difficulty in analyzing higher education trends is that all three of these theories are plausible, if partial, on their own. The trouble lies in their interstices. If students only acquire specialized knowledge, they are ill prepared for democratic decision-making. If they only acquire a broad liberal arts education, they are ill prepared for specialized job markets. Our analysis of the three core missions of the contemporary research university is similar to Menand's, in that it emphasizes how different conceptions of the goals of higher education go to the heart of contemporary controversies. However, Menand's typology focuses on the relationship between learning and the social charter, largely neglecting research and knowledge production, which is essential to any analysis of research-intensive institutions.

In the following sections, we review the three core missions of research-intensive universities and how each can create contradiction where they overlap. In particular, we highlight boundary disputes over the proper scope of university activities where market logics and business-oriented practices contradict academic values.

\section{Knowledge production: for transcendence or profit?}

A key boundary dilemma identified by the recent literature on university change is the extent to which research universities should produce knowledge that transcends shortterm problems for the sake of long-term scientific advancement, or, in contrast, focus on practical applications that can be efficiently transferred to industry or community stakeholders. This debate involves a concern that an overemphasis on problem-driven research can have a chilling effect on basic scientific discovery and exploratory studies.

Scholars have posed two ideal types that nicely capture this divide: the "old school traditionalists" and the "new school entrepreneurs," along with hybrid categories for faculty who combine elements of each (Lam 2010; Owen-Smith and Powell 2002). The "traditionalist" view is based on Mertonian scientific norms that stress disinterestedness, communal sharing of ideas, universalism, and organized skepticism (1973, [1942]). From this perspective, an emphasis on patenting and marketability of research can disrupt the transcendent ideal of unfettered academic freedom and knowledge production (Radder 2010).

Alternatively, advocates of knowledge capitalization typically embrace opportunities for industry or government partnership by engaging in patenting, developing startup companies, or pushing for university spinoffs that emphasize problem-driven research (Lam 2010; Owen-Smith and Powell 2002). From their perspective, the emphasis on basic science can lead to insular science and scholarship far removed from the practical needs of everyday life (see Geiger and Sá 2008). Markets for academic research are understood as a democratizing institution, bringing science to the masses and easing the transfer of technologies that enhance people's health and livelihood. Consider, for example, the current emphasis on "translational science" across numerous university campuses. Enhanced knowledge transfer, the reasoning goes, leads to science that is enlightening, transferable, and impactful while simultaneously securing continued financial solvency for research universities facing dwindling endowments and tightening public budgets.

The boundary work between these two visions has come to a head in the last two decades, particularly in the United States and United Kingdom university systems. Many policymakers and university administrations routinely argue that post-industrial economies are dependent on knowledge exchange between public and private institutions. This "knowledge economy" must be driven by ideas and innovation that can move across institutions, and large research-intensive universities provide competitive advantage in this 
environment. In addition, advocates of the push toward knowledge capitalization, particularly at public institutions, suggest that there is very little choice but to identify and alternative revenue if the university is survive budget cuts and fiscal austerity.

An effort to strengthen universities' intellectual property rights, ease restrictions on technology transfer, and increase competition for market-based research was codified in the US Bayh-Dole Act of 1980, which facilitated universities' ability to file and receive patents for publicly-funded university research (Berman 2008; Mowery et al. 2001). The UK passed similar legislation in 1985 (Etzkowitz et al. 2000). These laws, coupled with further regulatory changes in the 1980s, tightened the university-industry-government nexus and empowered university administrators to seek revenue from knowledge capitalization at an unprecedented level (Etzkowitz 2008; Rhoten and Powell 2007; Slaughter and Rhoades 2004). By 2000, two hundred American universities had established technology transfer offices with staff specialized in research policy and patent law, earning an estimated $\$ 1$ billion per year in fees and royalties (Bok 2003, 12).

This trend elicited wide-ranging concerns among scholars and university critics worried about a long-term shift toward research decisions based on material incentives, further state retrenchment from higher education, conflicts of interest, secrecy, and non-disclosure agreements with corporate clients that could curtail open discovery and student learning (Bok 2003; Krimsky 2004; Washburn 2005). More systematic research has begun to document how research decisions and methods get adapted to the interests of corporate and industry actors (Kleinman 2003; Murray 2010; Vallas and Kleinman 2008). Thus, while patenting and collaborations with corporate firms can provide new sources of income and innovation (Powell et al. 1996; Stokes 1997), they can also create new barriers to research (Welsh et al. 2008), some of which can include subtle shifts in academic culture (Slaughter et al. 2004; Vallas and Kleinman 2008). Kleinman's (2003) ethnography of a biology laboratory, for example, demonstrates that even when researchers report little to no conflicts of interest, an entire field of scientific research (plant pathology) can be based on baseline criteria derived from industry.

Macro-level shifts of university research toward formal university-industry relations can also have quite diffuse impacts on faculty and staff, including those with little to no involvement in direct industry ties. This can range from symbolic pressures to more pernicious disciplinary and research unit stratification (Hoffman 2011; Kleinman 2010; Ylijoki 2003). On the flip side, entrepreneurial researchers struggle to combine the demands of industry with traditional university needs. Some report feeling disaffected from academic culture (Lam 2010). In response, many of the self-identifying "new school" academics respond not only by critiquing Ivory Tower esotery but also with concerted efforts to redefine what counts as good science in the first place.

\section{Learning: for democracy or return on investment?}

Within the mission of student learning, a key boundary dilemma involves whether the goals of democratic citizenship can co-exist with demands for clearly demonstrable returns on educational investment. At stake is the very nature of skills we believe students should have upon leaving the institution.

This is evident in the complicated matter of how universities should construct students, as "learners" or as "consumers," "clients," or "customers." McMillan and Cheney (1996) note that there are some positive aspects of a consumer metaphor, including administrative transparency, in-class accountability, and a recognition that students have quite real material concerns with finding quality jobs after they graduate (see also Stevens et al. 2008). The UK 
provides potential students with several tools to choose schools that will provide the most return: results of the National Student Survey, surveys of graduate destinations, and the Unistats website help students "shop" for the greatest returns (Locke 2010).

However, this preoccupation with credentials and vocational training (Zemsky 1993) has been implicated in a departure from traditional conceptions of higher education as an enlightening and empowering experience vital to creating a well-rounded democratic citizenry (Gibbs 2001). McMillan and Cheney (1996) have cautioned that when education is reconfigured as a product as opposed to a service, students can become apathetic toward learning material that is challenging. Ritzer (1996) has warned that an emphasis on efficient processing of students may lead to production practices, institutions, and values similar to those that characterize the fast food industry. In such a climate, effective measures to enhance student learning might become secondary to cost effectiveness and output. Research has pointed to larger classrooms, fewer seminars, fewer full time professors, more short-term teaching contracts as indicators of this trend (Angelo 1999; Kezar 2005b). Scholars have also found preliminary evidence to suggest that the academic ethic is in a state of decline ( $\mathrm{Rau}$ and Durand 2000), that students show little demonstrable learning (Arum and Roksa 2011), or that consumer characteristics are becoming the norm among undergraduates (Delucchi and Korgen 2002; White 2007).

Furthermore, a growing research literature on student learning suggests that that the belief that market-based practices generate greater transparency, efficiency, and responsiveness may be misplaced. White (2007), for example, argues that in the Australian higher education system, an emphasis on treating students as consumers has created disengagement and a lowering of academic standards (for similar arguments in the US case, see Arum and Roksa 2011; Delucchi and Korgen 2002; Smith 2000). Research in the United States has identified worrisome trends toward student subcultures that prioritize grades over engagement, such as instrumental behavior aimed at identifying those courses and instructors most likely to improve individual's GPA (Delucchi and Korgen 2002). Some students even report an expectation that they be rewarded for effort alone, regardless of their formal performance (Smith 2000; White 2007). In fact, Delucchi and Korgen (2002) found that nearly half of the students they surveyed felt entitled to a degree by virtue of having paid tuition. These trends may be particularly acute at universities in which course offerings are held in large lecture halls led by research professors who have few institutional incentives to value their teaching beyond standardized reporting mechanisms.

The student-as-consumer model of pedagogy may also influence how students perceive the instruction that they receive from their teachers. White reports that the "passion" of the professor for the topic is the most important indicator of quality on student evaluations in Australia (2007). Over half of the American students surveyed by Delucchi and Korgen (2002) have come to rely on professors to keep their attention by expecting the professor to not just foster an effective learning environment but to do so in innovative, entertaining, and esthetically pleasing fashion. Some scholars (Hassel and Lourey 2005; Rabow and Hernandez 1988) suggest that the emphasis on highly quantified testing can create perverse incentives for students to internalize the notion that they, too, should seek the most efficient path to the credential, thereby putting in jeopardy a longer term commitment to liberal arts ideals.

\section{The social charter: for the public good or private gain?}

The third mission of the modern university is to meet the expectations of a social charter between the university and its surrounding community, nation, and increasingly, world. 
The boundary dilemma here revolves around whether that charter holds the university as a defender of civic development and collective identity, or as a purveyor of "instrumental individualism" (Sullivan 2000). Proponents of the latter view tend to redefine the broader sense of the social charter as economic growth (i.e. increasing jobs, urban development, profitable university-industry relations, etc.), whereas proponents of the former believe that economic growth should remain marginal to broader civic engagement programs. This trend is exemplified in the United Kingdom by the shift in the government policy narrative from the 1963 Robbins report to the 1997 Dearing report and also when the British Secretary of State for Education and Skills declared that the non-economic benefits of higher education are "over-rated" (Mayhew et al. 2004).

Boundary work around the social charter is nothing new. Since the 18th century, universities have traditionally carried the burden of developing civic identity among the elite (Mathews 2000) and addressing local concerns related to poverty, health, and urbanization (Kezar 2004; Sullivan 2000). This has particularly been the case for the public institutions in the United States and Europe, including the American land-grant institutions. However, for most of the 20th century, academic scholarship was also expected to develop on its own trajectory, characterized by neutrality and independence from outside influence. Based on English and Germanic traditions, scholars pursued basic research and scientific discovery that "traditionalists" (Bok 1982) argued would result in solutions to long-term social issues as opposed to quick fixes for more localized community problems.

The ideal of the university as an isolated laboratory for long-term theoretical and scientific development fell in and out of favor throughout the 20th century. Many US campuses were called upon to serve as makeshift boot camps and training centers in foreign studies and languages during WWII (Kezar 2004). In 1945, the US government began providing funding for cancer research and other endeavors to help the public good. By the 1950s, capstone courses to encourage moral responsibility among graduates disappeared at most American campuses, replaced by Western Civilization courses designed to teach students shared civic duties. The training of students for civic participation coupled with a growing focus on the provision of socially beneficial research findings became the university's responsibility within the traditional "social charter" (Chambers 2005a,b; Gumport 2007; Kezar 2004, 2005a). Society was, in turn, expected to contribute financial support.

Modern trends towards marketization have altered the character of this original charter to require less from universities in terms of civic development, subtly redefining the public good as vocational training and economic productivity. Research shows that faculty and administrators in the United States still express robust definitions of the public good and the university's responsibility in contributing to it (Chambers and Gopaul 2008; Mathews 2000). However, in practice many focus on industry collaborations (if measured by capital outlay). Kezar (2005a) warns that the social charter has been rewritten with the university's responsibility conceived in strictly economic terms.

Although as nonprofit institutions, American research universities are not required to pay state property taxes, universities contribute significant revenue through faculty, staff, student, and visitor spending at local businesses. In addition, the school itself spends a considerable amount in the community, as do the employees of businesses that opened specifically to serve university students, and property values around a university rise and surrounding neighborhoods gain access to museums, libraries, athletic facilities, tutoring, legal services, and medical care (Bok 1982). Kezar (2005a) and Sullivan (2000) suggest that some research universities now measure success in terms of their ability to produce economic returns for taxpayer investment. Such econometric calculations of academic 
value can marginalize departments in the social sciences and humanities as well as public service that that are removed from market potential.

Some scholars suggest that students in this environment focus on instrumental goals, which can create widespread apathy toward civic engagement (Bok 1990). There is some empirical evidence to support this position. Between 1973 and 1993, overall student attendance for rallies and speeches have dropped 36 percent in the United States, local town and school related meeting attendance has dropped 39 percent, and participation in political parties have diminished 56 percent. Even participation in social activities such as PTA, the Red Cross, and the League of Women Voters has dropped as much as 50 percent (Putnam 1996).

Scholars engage in significant boundary work as they grapple with the appropriate role of the university within its local and extra-local communities. Scholars have sought to reinstitute the original social charter requiring higher education to promote community involvement and civic growth (Chambers 2005a; Kezar 2005b). Others argue that the university should retreat from external involvement all together, suggesting that the mission to serve society has led the university to overextend itself in ways that leave it exposed to economic and political influences that corrupt traditional academic values. They argue that a return to a detached and value-free university will ensure discovery and education that will ultimately address the most important social issues in the long run.

\section{Conclusion}

The implicit question raised by nearly all the literature on the marketization of higher education is whether a value-set that privileges knowledge creation and learning is being overtaken by economic instrumentalism. This question goes to the heart of the debates over the boundaries of the contemporary academy as universities and colleges face increasing pressures and incentives to become less dependent on federal grants and state support.

What will come of the 21st century university in the United States and Europe? If continued unabated, the marketization pressures we have discussed suggest increased segmentation across types of universities, and many large research universities moving increasingly toward market-driven revenue generation and away from public funding (with, of course, the caveats and contingencies noted in the United States and European comparisons noted above). This trend will exacerbate the disaffection among those academic units and faculty furthest removed from market potential. In the United States, this may lead to the shrinking and perhaps disappearance of many non-research-based state colleges, as they are ill-situated to weather the retrenchment of public support. The gaps they leave will likely be filled by already underfunded and overcrowded community colleges, specialized degree institutions, and for-profit colleges. In other words, we see an escalation of the dilemmas, problems, and contradictions described in this article. It could be that large-scale social and economic changes are just around the corner. In the meantime, much research remains to be done.

A key area for future study is to develop a better understanding of how marketization plays out among very different types of higher education institutions. Davies and Quirke (2007) have made important steps in this regard with their analysis of different types of high schools. Their analysis demonstrates that elite private, non-elite private, and public schools differ sharply in their responses to market pressures. Similar analysis could be extended to colleges and universities. The institutional missions and overall sense of purpose 
of 2-year community colleges and top-tier public research universities are very different and are likely to become more so, as are those in 2- and 4-year private liberal arts colleges, technical institutes, vocational schools, and increasingly popular online degree schools.

Work by Shore $(2008,2010)$ highlights that solutions sometimes exacerbate the problems they are designed to remedy. Amid the growing outcry about the effectiveness of today's educational institutions and calls for greater accountability, continued research on the effects of marketization in the directions proscribed above can help to channel these debates in fruitful directions. Understanding the processes at work and the institutional responses to them can reveal the shortcomings of today's higher education practices, which in turn can lay the foundation for alleviating deficiencies, inequalities, and unintended consequences of new revenue generation schemes. This will only be possible, however, if scholars continue to focus on the inherent contradictions between the contemporary university's three institutional missions. Sputnik moment or not, we all should heed the American President's call to maintain higher education's relevance to our global and local societies.

\section{Short Biographies}

Daniel H. Nickolai is a PhD candidate at the University at Buffalo, SUNY. He holds an MA in Sociology and a BA in Sociology and Legal Studies. His research interests are in the areas of the sociology of teaching and learning, education, criminology, and cultural sociology. His dissertation research examines the effects of the marketization of higher education on the experiences of students.

Steve G. Hoffman is an Assistant Professor of Sociology at the University at Buffalo, SUNY. His research interests reside at the intersection of organizational studies, social psychology, and science studies. Lately he has been writing a lot about academic capitalism and the 21st century research university. Representative publications can be found in the journals Sociological Theory, Sociological Inquiry, Law \& Society Review, Sociological Forum, Social Anthropology, and Sociology Compass.

Mary Nell Trautner, PhD, is an assistant professor of sociology at the University at Buffalo, SUNY. Her interests are in the areas of law and society, gender and the body, and work and organizations. Her current work focuses on legal decision-making and public policy. Her articles appear in American Sociological Review, Symbolic Interaction, and Gender \& Society.

\section{Note}

* Correspondence address: Daniel H. Nickolai, Department of Sociology, University at Buffalo, SUNY, 430 Park Hall, Buffalo, NY 14260, USA. E-mail: nickolai@buffalo.edu

\section{References}

Adams, Mike S. 2004. Welcome to the Ivory Tower of Babel: Confessions of a Conservative College Professor. Boyne City, MI: Harbor House.

Agasisti, Tommaso and Giuseppe Catalano. 2006. 'Governance Models of University Systems - Towards QuasiMarkets? Tendencies and Perspectives: A European Comparison.' Journal of Higher Education Policy and Management 28: $245-62$.

Angelo, Thomas A. 1999. 'The Campus as a Learning Community: Seven Promising Shifts and Seven Powerful Levers.' Pp. 110-6 in The Social Worlds of Higher Education: Handbook for Teaching in a New Century, edited by B. Pescosolido and R. Aminzade. Thousand Oaks, CA: Pine Forge Press. 
Arum, Richard and Josipa Roksa. 2011. Academically Adrift: Limited Learning on College Campuses. Chicago, IL: University of Chicago Press.

Barnett, Ronald. 2010. 'The Marketised University: Defending the Indefensible.' Pp. 39-51 in The Marketisation of Higher Education and the Student as Consumer, edited by M. Molesworth, R. Scullion and E. Nixon. New York, NY: Routledge.

Berman, Elizabeth Popp. 2008. 'Why Did Universities Start Patenting? Institution-Building and the Road to the Bayh-Dole Act.' Social Studies of Science 38: 835-71.

Bok, Derek. 1982. Beyond the Ivory Tower: Social Responsibilities of the Modern University. Cambridge, MA: Harvard University Press.

Bok, Derek. 1990. Universities and the Future of America. Durham, NC: Duke University Press.

Bok, Derek. 2003. Universities in the Marketplace: The Commercialization of Higher Education. Princeton, NJ: Princeton University Press.

Chambers, Tony. 2005a. 'Pondering the Social Charter: Critical Reflection for Leaders.' Pp. 326-30 in Higher Education for the Public Good, edited by A. Kezar, T. C. Chambers and J. C. Burkhardt. San Francisco, CA: Jossey-Bass.

Chambers, Tony. 2005b. 'The Special Role of Higher Education in Society: As a Public Good for the Public Good.' Pp. 3-22 in Higher Education for the Public Good, edited by A. Kezar, T. C. Chambers and J. C. Burkhardt. San Francisco, CA: Jossey-Bass.

Chambers, Tony and Bryan Gopaul. 2008. 'Decoding the Public Good of Higher Education.' Journal of Higher Education Outreach 12: 59-91.

Cohen, Arthur and Carrie Kisker. 2010. The Shaping of American Higher Education: Emergence and Growth of the Contemporary System. San Francisco, CA: John Wiley \& Sons, Inc.

Davies, Scott and Linda Quirke. 2007. 'The Impact of Sector on School Organizations: Institutional and Market Logics.' Sociology of Education 80: 66-89.

Delucchi, Michael and Kathleen Korgen. 2002. 'We're the Customer - We Pay the Tuition': Student Consumerism Among Undergraduate Sociology Major.' Teaching Sociology 30: 100-7.

Dolenec, Danijela. 2006. 'Marketization in Higher Education Policy: An Analysis of Higher Education Funding Policy Reforms in Western Europe between 1980 and 2000.' Croatian Journal of Social Policy 13: 15-35.

Etzkowitz, Henry. 1998. 'The Norms of Entrepreneurial Science: Cognitive Effects of the New University-Industry Linkages.' Research Policy 27: 823-33.

Etzkowitz, Henry. 2008. The Triple Helix: University-Industry-Government Innovation in Action. New York, NY: Routledge.

Etzkowitz, Henry, Andrew Webster, Christiane Gebhardt and Branca Regina Cantisano Terra. 2000. 'The Future of the University and the University of the Future: Evolution of Ivory Tower to Entrepreneurial Paradigm.' Research Policy 29: 313-30.

Foucault, Michel. 1973 [1966]. The Order of Things: An Archaeology of the Human Sciences. New York, NY: Vintage.

Foucault, Michel. 1975. Discipline \& Punish: The Birth of the Prison. New York, NY: Random House.

Frank, David John and Jay Gabler. 2006. Reconstructing the University: Worldwide Shifts in Academia in the 20th Century. Stanford, CA: Stanford University Press.

Geiger, Roger L. and Creso M. Sá. 2008. Tapping the Riches of Science: Universities and the Promise of Economic Growth. Cambridge, MA: Harvard University Press.

Gibbs, Paul. 2001. 'Higher Education as a Market: A Problem or Solution?' Studies in Higher Education 26: 86-94.

Gumport, Patricia J. 2007. 'Sociology of Higher Education: An Evolving Field.' Pp. 17-52 in Sociology of Higher Education: Contributions and Their Contexts, edited by P. J. Gumport. Baltimore, MD: Johns Hopkins Press.

Hassel, Holly and Jessica Lourey. 2005. 'The Dea(r)th of Student Responsibility.' College Teaching 53: 2-13.

Hoffman, Steve G. 2011. 'The New Tools of the Science Trade: Contested Knowledge Production and the Conceptual Vocabularies of Academic Capitalism.' Social Anthropology 19: 439-62.

Jencks, Christopher and David Riesman. 1968. The Academic Revolution. New York, NY: Doubleday.

Joughin, Gordon. 2010. 'The Hidden Curriculum Revisited: A Critical Review of Research into the Influence of Summative Assessment on Learning.' Assessment \& Evaluation in Higher Educational Policy 35: 335-45.

Kezar, Adrianna J. 2004. 'Obtaining Integrity? Reviewing and Examining the Charter between Higher Education and Society.' The Review of Higher Education 27: 429-59.

Kezar, Adrianna J. 2005a. 'Challenges for Higher Education in Serving the Public Good.' Pp. 23-42 in Higher Education for the Public Good, edited by A. Kezar, T. C. Chambers and J. C. Burkhardt. San Francisco, CA: JosseyBass.

Kezar, Adrianna J. 2005b. 'Creating a Metamovement: A Vision Toward Regaining the Public Social Charter.' Pp. 43-54 in Higher Education for the Public Good, edited by A. Kezar, T. C. Chambers and J. C. Burkhardt. San Francisco, CA: Jossey-Bass.

Klein, Daniel. 2005. 'The Ph.D. Circle in Academic Economics.' Econ Journal Watch 2: 133-48.

Kleinman, Daniel Lee. 2003. Impure Cultures: University Biology and the World of Commerce. Madison, WI: University of Wisconsin Press. 
Kleinman, Daniel Lee. 2010. 'The Commercialization of Academic Culture and the Future of the University.' Pp. 24-64 in The Commodification of Academic Research: Science and the Modern University, edited by H. Radder. Pittsburgh, PA: University of Pittsburgh Press.

Krimsky, Sheldon. 2004. Science in the Private Interest: Has the Lure of Profits Corrupted Biomedical Research? Lanham, MD: Rowman \& Littlefield Publishers.

Lam, A. 2010. 'From 'Ivory Tower Traditionalists' to 'Entrepreneurial Scientists'? Academic Scientists in Fuzzy University-Industry Boundaries.' Social Studies of Science 40: 307-40.

Lemann, Nicholas. 1999. The Big Test: The Secret History of the American Meritocracy. New York, NY: Farrar, Straus and Giroux.

Leslie, Larry L. and Gary P. Johnson. 1974. 'The Market Model and Higher Education.' The Journal of Higher Education 45: 1-20.

Locke, William. 2010. 'False Economy? Multiple Markets, Reputational Hierarchy and Incremental Policy Making in UK Higher Education.' Pp. 74-85 in Higher Education and the Market, edited by R. Brown. New York and London: Routledge.

Mathews, David. 2000. 'How Concepts of Politics Control Concepts of Civic Responsibility.' Pp. 149-62 in Civic Responsibility and Higher Education, edited by T. Ehrlich. Phoenix, AZ: The Oryx Press.

Mayhew, Ken, Cecil Deer and Mehak Dua. 2004. 'The Move to Mass Higher Education in the UK: Many Questions and Some Answers.' Oxford Review of Education 30: 65-82.

McMillan, Jill J. and George Cheney. 1996. 'The Student as Consumer: The Implications and Limitations of a Metaphor.' Communication Education 45: 1-15.

Menand, Louis. 2010. The Marketplace of Ideas: Reform and Resistance in the American University. New York, NY: W.W. Norton \& Company.

Menand, Louis. 2011. 'Live and Learn: Why We Have College.' The New Yorker 87(16):74-9.

Merton, Robert. 1973 [1942]. 'The Normative Structure of Science.' Pp. 267-80 in The Sociology of Science, edited by R. Merton. Chicago, IL: University of Chicago Press.

Moser, Claus. 1988. 'The Robbins Report - 25 Years After and the Future of Universities.' Oxford Review of Education 14: 5-20.

Mowery, David C., Richard R. Nelson, Bhaven N. Sampat and Arvids A. Ziedonis. 2001. 'The Growth of Patenting and Licensing by U.S. Universities: An Assessment of the Effects of the Bayh-Dole Act of 1980.' Research Policy 30: 99-119.

Mulnix, Michael. 1990. 'College Students as Consumers: A Brief History of Educational Marketing.' Journal of Marketing for Higher Education 2: 123-49.

Murray, Fiona. 2010. 'The Oncomouse that Roared: Hybrid Exchange Strategies as a Source of Distinction at the Boundary of Overlapping Institutions.' American Journal of Sociology 116: 341-88.

Owen-Smith, Jason and Walter W. Powell. 2002. 'Standing on Shifting Terrain: Faculty Responses to the Transformation of Knowledge and Its Uses in the Life Sciences.' Science Studies 15: 3-28.

Oxlund, Bjarke. 2010. 'Responding to University Reform in South Africa: Student Activism at the University of Limpopo.' Social Anthropology 18: 30-42.

Powell, Walter W., Kenneth W. Koput and Laurel Smith-Doerr. 1996. 'Interorganizational Collaboration and the Locus of Innovation: Networks of Learning in Biotechnology.' Administrative Science Quarterly 41: 116-45.

Professor X. 2011. In the Basement of the Ivory Tower: Confessions of an Accidental Academic: Viking Adult. New York, NY: Viking Adult.

Putnam, Robert D. 1996. 'The Strange Disappearance of Civic America.' The American Prospect 24: 34-49.

Rabow, Jeromy and Anthony C. R. Hernandez. 1988. 'The Price of the GPA Perspective: An Empirical Study of 'Making the Grade.' Youth and Society 19: 363-77.

Radder, Hans. 2010. The Commodification of Academic Research: Science and the Modern University. Pittsburgh, PA: University of Pittsburgh Press.

Rau, William and Ann Durand. 2000. 'The Academic Ethic and College Grades: Does Hard Work Help Students to "Make the Grade?"' Sociology of Education 73: 19-38.

Rhoten, Diana and Walter W. Powell. 2007. 'The Frontiers of Intellectual Property: Expanded Protection Versus New Models of Open Science.' Annual Review of Law and Social Science 3: 345-73.

Ritzer, George. 1996. 'McUniversity in the Postmodern Consumer Society.' Quality in Higher Education 2: 185-99.

Sauder, Michael and Wendy Nelson Espeland. 2009. 'The Discipline of Rankings: Tight Coupling and Organizational Change.' American Sociological Review 74: 63-82.

Shore, Cris. 2008. 'Audit Culture and Illiberal Governance.' Anthropological Theory 8: 278-98.

Shore, Cris. 2010. 'Beyond the Multiversity: Neoliberalism and the Rise of the Schizophrenic University.' Social Anthropology 18: 15-29.

Shore, Cris. 2011. 'How Commercialisation is Redefining the Mission and Meaning of the University: A Reply to Steve G. Hoffman.' Social Anthropology 19: 495-9.

Shore, Cris and Susan Wright. 2000. 'Coercive Accountability: The Rise of Audit Culture in Higher Education.' Pp. 57-89 in Audit Cultures, edited by M. Strathern. London: Routledge. 
Slaughter, Sheila, Cynthia Joan Archerd and Teresa I. D. Campbell. 2004. 'Boundaries and Quandaries: How Professors Negotiate Market Relations.' The Review of Higher Education 28: 129-65.

Slaughter, Sheila and Gary Rhoades. 2004. Academic Capitalism and the New Economy: Markets, State, and Higher Education. Baltimore, MD: The Johns Hopkins University Press.

Smith, William L. 2000. 'Teaching in a Consumeristically Charged Environment.' Michigan Sociological Review 14: 58-72.

Stevens, Mitchell L., Elizabeth A. Armstrong and Richard Arum. 2008. 'Sieve, Incubator, Temple, Hub: Empirical and Theoretical Advances in the Sociology of Higher Education.' Annual Review of Sociology 34: 127-51.

Stokes, Donald. 1997. Pasteur's Quadrant: Basic Science and Technological Innovation. Washington, DC: Brookings Institution Press.

Subotzky, George. 1999. 'Alternatives to the Entrepreneurial University: New Modes of Knowledge Production in Community Service Programs.' Higher Education 38: 401-40.

Sullivan, William M. 2000. 'Institutional Identity and Social Responsibility in Higher Education.' Pp. 19-36 in Civic Responsibility and Higher Education, edited by T. Ehrlich. Phoenix, AZ: The Oryx Press.

Thomas, Nancy L. 2000. 'The College and University as Citizen.' Pp. 63-97 in Civic Responsibility and Higher Education, edited by T. Ehrlich. Phoenix, AZ: The Oryx Press.

U.S. Department of Education. 2010. Digest of Education Statistics (NCES 2010-013). Washington, D.C.: U.S. Department of Education.

Vallas, Steven Peter and Daniel Lee Kleinman. 2008. 'Contradiction, Convergence and the Knowledge Economy: The Confluence of Academic and Commercial Biotechnology.' Socio-Economic Review 6: 283-311.

Walshok, Mary Lindenstein. 2000. 'A Research University Perspective.' Pp. 295-306 in Civic Responsibility and Higher Education, edited by T. Ehrlich. Phoenix, AZ: The Oryx Press.

Washburn, Jennifer. 2005. University, Inc.: The Corporate Corruption of Higher Education. New York, NY: Basic Books.

Welsh, Rick, Leland Glenna, William Lacy and Dina Biscotti. 2008. 'Close Enough But Not Too Far: Assessing the Effects of University-Industry Research Relationships and the Rise of Academic Capitalism.' Research Policy 37: 1854-64.

White, Naomi Rush. 2007. “"The Customer is Always Right?”: Student Discourse About Higher Education in Australia.' Higher Education 54: 593-604.

Wright, Susan and Annika Rabo. 2010. 'Introduction: Anthropologies of University Reform.' Social Anthropology 18: $1-14$.

Ylijoki, Oili-Helena. 2003. 'Entangled in Academic Capitalism? A Case-Study on Changing Ideals and Practices of University Research.' Higher Education 45: 307-35.

Zemsky, Robert. 1993. 'Consumer Markets and Higher Education.' Liberal Education 79: 14-7. 